\title{
The alcohol taxation system in European Union and Croatia
}

\author{
PETAR SOPEK ${ }^{\mathrm{I}}$ Privredna banka Zagreb
}

Alcohol taxation has social, health and economic implications. However, the main reason for the imposition of excise duties is almost always fiscal, i.e. the consequent increase in public revenues. For EU Member States there is only a Directive concerning minimum rates of alcohol and alcoholic beverage taxation, thus there are evidently numerous differences in the application of excise duties and in the budget revenues deriving from alcohol levies. Therefore, in the European alcohol taxation system there is some space for further harmonization of rates, but also harmonization of exemptions and categorizations of certain products. Moreover, there is a need for the establishment of quality capacities for fight against smuggling as well as the harmonization of health and social policy objectives with those of the agricultural policy. This is especially pronounced in the context of supporting wine production. Croatian excise duties on alcohol and alcoholic beverages are fully compliant with minimum requirements and rates set by the EU.

\section{INTRODUGTION}

The alcohol problem is one of the world's top priorities in the public health area. Apart from being a drug of dependence, alcohol is a cause of some 6o different types of diseases and conditions, including injuries, mental, behavioural, immunological and reproductive disorders, cardiovascular, skeletal, muscular, liver and lung diseases, gastrointestinal conditions and cancers (Anderson and Baumberg, 2006:4). Alcohol is the third most significant risk factor for ill health and premature death in the European Union (EU), right behind tobacco and high blood pressure. The EU is the region with the highest alcohol consumption in the world. In 2009, the average adult (aged I5+ years) alcohol consumption in the EU was I2.5 litres of pure alcohol, that is $27 \mathrm{~g}$ of pure alcohol or nearly three drinks a day, which is more than double the world average (WHO, 2OI2:I).

Besides value added tax (VAT), alcohol and alcoholic beverages in both the EU and Croatia are additionally taxed by excise duties, and the duty is levied in an absolute amount on the defined ${ }^{\mathrm{I}}$ This paper should not be reported as representing the views of Privredna banka Zagreb. The views expressed in this
paper are exclusively those of the author and do not necessarily represent those of PBZ. 
tax base. There are various objectives in the imposition of excise duties on alcohol, from encouraging a decrease in consumption (health and social motives), annulation of all external ${ }^{2}$ and total social costs (economic and social motives) or raising revenue for general purposes (fiscal motive). Various studies (Smith, 2005; Cnossen, 2006; Rabinovich et al, 2012) found a negative elasticity of alcohol consumption on price, meaning that an increase in the prices of alcohol beverages induces a decrease in consumption. Elasticity varies depending on the type of alcohol beverage, i.e. the lowest is mainly on beer and the highest on spirits. Moreover, the long-run price elasticity of alcohol demand is significantly higher than the short-run elasticity and moderate drinkers are more price responsive than heavy drinkers (Cnossen, 2006:23-25). In other words, alcohol consumption significantly depends on consumer habits and hence the question of addiction can definitely not be ignored. Some of the individual and external costs of alcohol consumption arise as a result of the addictive nature of consumption, which is an additional dimension to the problem.

Given the numerous differences in the rates applied in various EU countries it is obvious that there is no consensus on the optimal amounts of excise duty such as to cancel external and total social costs and diminish the total negative effects of alcohol consumption. This actually means that the existing system of alcoholic beverage taxation is based on different principles than those stated above, i.e. very often, economic, or rather, fiscal impacts are the main rationale for tax imposition.

Nevertheless, the alcohol and alcoholic beverages taxation policy should reflect the optimal integration of all the desired impacts. The main objective of this paper is to provide a short overview of the alcohol taxation system in the EU, compare it with that in Croatia and show the most important differences among Member States. Furthermore, this paper will endeavour to identify key shortcomings in the existing European alcohol taxation system, which will probably represent important factors in decision making on the harmonisation of future legislation.

\section{THE ALGOHOL TAXATION LEGISLATIVE FRAMEWORK}

Commonly regulated taxation on alcohol and alcoholic beverages for the EU Member States has been in force since I January 1993, according to Council Directive 92/83/EEC of 19 October 1992 on the harmonization of the structures of excise duties on alcohol and alcoholic beverages. This Directive prescribes:

- the various categories of alcoholic beverage (beer, wine, fermented beverages other than beer and wine, intermediate products and ethyl alcohol),

- the basis on which the excise duty is calculated,

- the possibilities for the application of reduced rates for small independent breweries whose annual production does not exceed 200,00o hectolitres and small independent distilleries whose annual production does not exceed to hectolitres, as well as the application of reduced rate for certain drinks,

- special provisions of taxation for certain regions of Spain,

- derogations to exempt certain drinks in the United Kingdom,

- a general exemption for alcohol not intended for consumption as a beverage, i.e. exemption for denatured alcohol and alcohol used in the pharmaceutical, cosmetics, food and similar industries.

\footnotetext{
${ }^{2}$ Externality or external effect is an effect resulted from an activity of an individual directly affecting another individual's well-being, whereby this activity is not realized through market prices. Direct externalities generated by alcohol consumption are for instance car accidents caused by drunk-driving in which some other person is hurt, damage to other people's property or violence. The second category of externalities comprises collectively borne costs, such as the cost of publicly funded medical treatment for alcohol-related conditions. There is also the third category of externalities which arise through the tax system, since alcohol consumption may have consequences for the individual consumer's income and expenditure (Smith, 2005:68).
} 
- Council Directive 92/84/EEC of 19 October 1992 on the approximation of the rates of excise duty on alcohol and alcoholic beverages sets the minimum rates of excise duties for alcohol and alcoholic beverages as follows ${ }^{3}$ :

- 550 EUR per hectolitre of pure alcohol for alcohol (spirits) contained in other alcoholic beverages, or I,Ooo EUR per hectolitre of pure alcohol for those countries that already applied excise duties on those products in amounts above I,Ooo EUR at the moment the Directive entered into force,

- 45 EUR per hectolitre of product for intermediate products (e.g. dessert wines, liquors),

- Zero rate for wine and sparkling wine,

- $\quad$ o.748 EUR per hectolitre of finished product per degree Plato or I.87 EUR per hectolitre of finished product per degree alcohol for beer.

The above stated two Directives are supplemented by Commission Regulation (EC) No 3199/93 of 22 November 1993 on the mutual recognition of procedures for the complete denaturing of alcohol for the purposes of exemption from excise duty, which implements Article 27(I)(a) of the Council Directive 92/83/EEC for the complete denaturing of alcohol and sets down the various formulations of denaturants in the Member States. Apart from the mentioned legal framework, separate Council Decisions resolve some specific questions like authorisations for the application of a reduced rate of excise duty on certain products and regions in France and Portugal.

The legislative framework of the commonly arranged taxation of alcohol and alcoholic beverages for EU Member States prescribes only minimum rates of excise duties for certain types of alcoholic beverages. Member States may individually determine their own rates of excise duties above the minimum, in line with their national policies. Therefore, there are significant differences in the application of standard excise duty rates at the EU level (comparison of actual standard rates of excise duties by Member States is shown in Figures AI-A5 in the Appendix), as well as the application of reduced rates. It can be said that the alcohol and alcoholic beverages taxation system is not fully harmonized or ideally commonly arranged at the level of EU.

Table I

Classification of alcoholic beverages according to Directive 92/83/EEC and Combined Nomenclature

\begin{tabular}{|c|c|c|c|c|c|c|c|c|c|c|c|}
\hline \multicolumn{2}{|c|}{ Combined nomenclature } & \multicolumn{2}{|c|}{ Beer } & \multicolumn{2}{|c|}{ Wine } & \multicolumn{2}{|c|}{$\begin{array}{l}\text { Fermented } \\
\text { beverages }\end{array}$} & \multicolumn{2}{|c|}{$\begin{array}{l}\text { Intermediate } \\
\text { products }\end{array}$} & \multicolumn{2}{|c|}{$\begin{array}{l}\text { Ethyl } \\
\text { alcohol }\end{array}$} \\
\hline $22 \mathrm{O} 3$ & Beer made from malt & $\mathrm{X}$ & & & & & & & & & \\
\hline $22 \mathrm{O} 4$ & $\begin{array}{l}\text { Wine of fresh grapes, including } \\
\text { fortified wine }\end{array}$ & & & $\mathrm{X}$ & $\mathrm{X}$ & $\mathrm{X}$ & $\mathrm{X}$ & $\mathrm{X}$ & $\mathrm{X}$ & & $\mathrm{X}$ \\
\hline 2205 & $\begin{array}{l}\text { Vermouth and other wine of } \\
\text { fresh grapes flavoured }\end{array}$ & & & $\mathrm{x}$ & $\mathrm{X}$ & $\mathrm{X}$ & $\mathrm{X}$ & $\mathrm{X}$ & $\mathrm{X}$ & & $\mathrm{X}$ \\
\hline 2206 & Other fermented beverages & & $\mathrm{X}$ & & & $\mathrm{X}$ & $\mathrm{X}$ & $\mathrm{X}$ & $\mathrm{X}$ & & $\mathrm{X}$ \\
\hline 2207 & $\begin{array}{l}\text { Undenatured ethyl alcohol of } \\
\text { an alcoholic strength } \\
\text { exceeding } 80 \% \text { alcohol by } \\
\text { volume, denatured alcohol of } \\
\text { any strength }\end{array}$ & & & & & & & & & $\mathrm{X}$ & \\
\hline 2208 & $\begin{array}{l}\text { Undenatured ethyl alcohol of } \\
\text { an alcoholic strength less than } \\
80 \% \text { alcohol by volume; Spirits, } \\
\text { liquors and other spirituous } \\
\text { beverages }\end{array}$ & & & & & & & & & $\mathrm{X}$ & \\
\hline \multicolumn{2}{|c|}{ Alcohol by volume (in \%) } & $>0.5$ & $>0.5$ & $\begin{array}{l}>\mathrm{I} .2 \\
<\mathrm{I} 5\end{array}$ & $\begin{array}{l}>\text { I5 } \\
<\mathrm{I} 8\end{array}$ & $\begin{array}{l}>\mathrm{I} .2 \\
<\mathrm{IO}\end{array}$ & $\begin{array}{l}>\mathrm{IO} \\
<\mathrm{I} 5\end{array}$ & $\begin{array}{l}>\mathrm{I} .2 \\
<22\end{array}$ & $>5.5$ & $>\mathrm{I} .2$ & $\begin{array}{l}>2 \\
2\end{array}$ \\
\hline
\end{tabular}

Source: London Economics (20IO)

${ }^{3}$ As well as minimum rates for alcohol and alcoholic beverages, Council Directive 92/84/EEC also prescribes special taxation provisions for certain regions of Greece, Italy and Portugal. 
Taxable products in the EU are defined according to Combined Nomenclature (CN) classification of goods, which is extremely important for the application of adequate taxation treatment, but also for some other reasons like statistics and customs service needs. The Combined Nomenclature classification of alcoholic beverages by categories from Directive 92/83/EEC is shown in Table I.

In Croatia the excise duty imposed on alcohol and alcoholic beverages is regulated by the Excise Duty Act (Official Gazette 83/o9, III/I2 and 22/I3), while the application provisions of Excise Duty Act are laid down in Regulation implementing the Excise Duty Act (OG I/IO). Definitions of taxable products from the Croatian legal framework are also harmonized with Combined Nomenclature as shown in Table I. Tax bases and excise duties are defined as follows:

- The tax base on beer is I\% of pure alcohol contained in one hectolitre of finished product, and the excise duty is paid in the amount of 40 HRK.

- The tax base on still and sparkling wine, other beverages obtained by fermentation other than beer and wine and intermediate products is one hectolitre of finished product. Excise duty on still and sparkling wine, as well as other beverages obtained by fermentation other than beer and wine amounts to zero HRK. The excise duty on intermediate products with alcohol by volume of $15 \%$ and higher is paid in the amount of 800 HRK, while for intermediate products with alcohol by volume of less than $15 \%$ duty in the amount of 500 HRK per hectolitre of finished product is paid.

- The tax base on ethyl alcohol is one hectolitre of pure alcohol expressed as volume percentage measured at $20^{\circ} \mathrm{C}$, and is paid in the amount of 5,300 HRK.

It can be concluded that Croatian excise duties on alcohol and alcoholic beverages are fully harmonized with the minimum requirements and rates set by the EU Directives. As in European legislation, there are some tax exemptions, like those for exported goods, for alcohol which is used in pharmaceutical, cosmetics, food and similar industries etc. The new Excise Duty Act (OG 22/13), by which Council Directive 92/83/EEZ and Council Directive 92/84/EEZ are implemented into the legislation of the Republic of Croatia, will mainly enter into force on the date of Croatian accession to the $\mathrm{EU}^{4}$ No changes of the amounts of excise duties on alcohol and alcoholic beverages are envisaged by the new Act.

\section{ANALYSIS OF EXGISE DUTY REVENUE}

The importance of revenues from excise duties on alcohol and alcoholic beverages significantly depends on the national policy of the taxation of alcohol and alcoholic beverages, agricultural, health and ecological policies, the tradition of the consumption and the total consumption of alcohol, the size of legal cross-border trade and illegal activities like smuggling and other forms of tax evasion. Therefore, the share of revenues from excise duties on alcohol and alcoholic beverages in total tax revenues significantly differs in the different Member States, which is shown on Figure I.

Irrespective of significant differences among the observed EU Member States, it is evident that the revenues from excise duties on alcohol and alcoholic beverages are relatively small in size compared to total tax revenues, and total budget revenues of Member States. The average share of revenues from excise duties on alcohol and alcoholic beverages in total tax revenues (without social contributions) of EU-27 amounted to $0.91 \%$ in 2OII, the share in total general government revenues amounted to $0.54 \%$ and in GDP of $0.24 \%$. In this context, the Croatian figures are

\footnotetext{
${ }^{4}$ The whole chapter XVI (articles 53-69) in which basic fundamentals of alcohol and alcoholic beverages taxation are laid down (subjects to taxation, tax base, excise duty amounts, exemptions from taxation etc.) enters into force on the day of Croatian accession to the EU.
} 
slightly above the EU-27 average with the share of revenues from excise duties on alcohol and alcoholic beverages in total tax revenues of 1.I8\%, in total general government revenues of $0.67 \%$ and in GDP of $0.25 \%$. Figure 2 shows the structure of revenues from EU harmonized excise duties in $2 \mathrm{OII}^{5}$.

\section{Figure I}

Share of revenues from excise duties on alcohol and alcoholic beverages in total tax revenues (exclusive of social contributions) in 2OII, in percentages

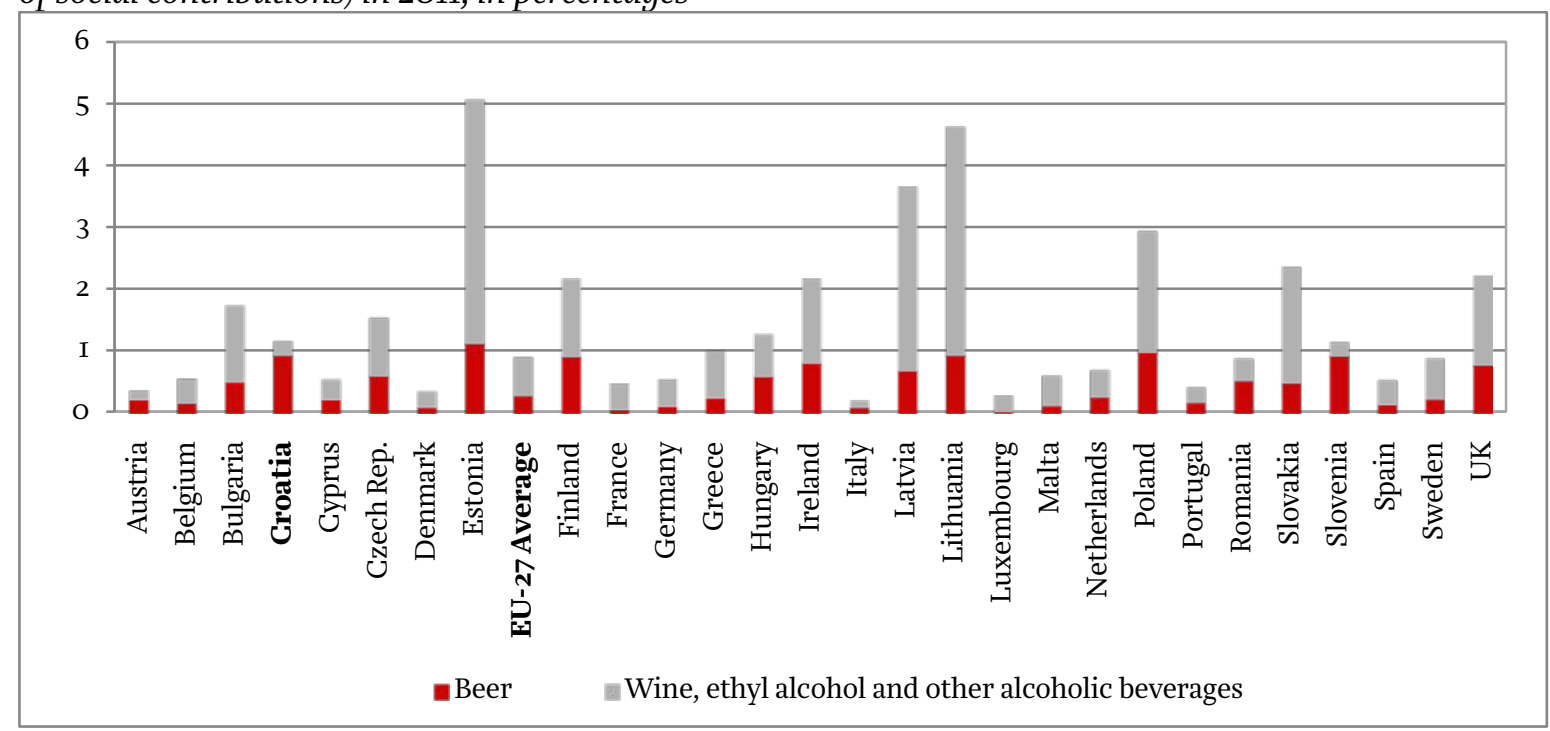

Source: Author's adjustment based on European Commission (2012a), Eurostat and Ministry of Finance

\section{Figure 2}

Structure of revenues from harmonized excise duties of EU-27 and Croatia in 2OII, in percentages

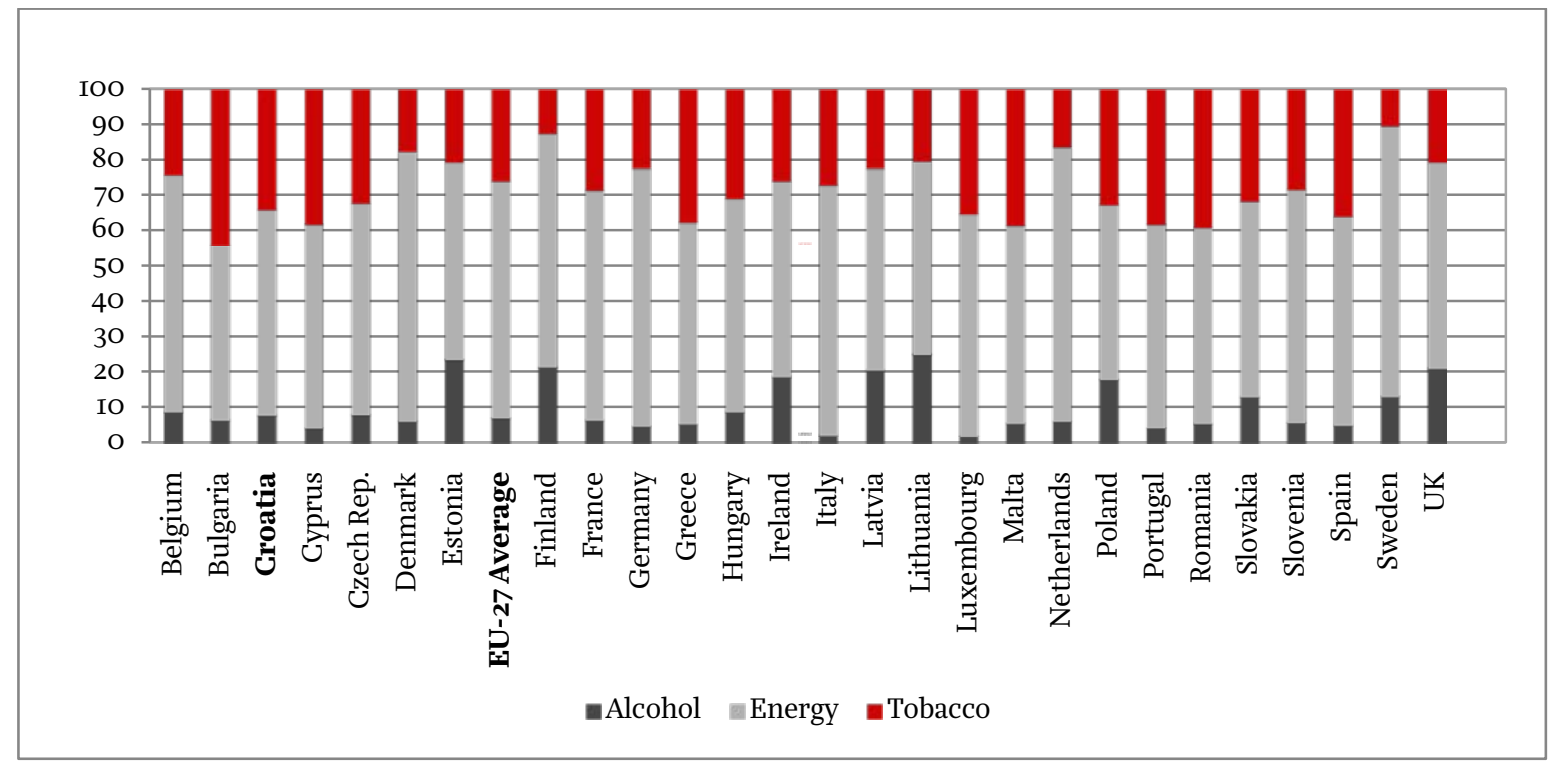

Source: Author's adjustment based on European Commission (20I2a; 20I2b; 20I2c) and Ministry of Finance

${ }^{5} \mathrm{EU}$ harmonized excise duties denote excise duties on the group of products for which the legal framework was set up on the establishment of internal market on I January 1993. These are alcohol and alcoholic beverages, tobacco products and energy products and electricity. Revenues from these excise duties represent the largest share of total excise duties receipts. According to Taxes in Europe database (European Commission), the share of unharmonized excise duties in total excise duties receipts is relatively significant only in the cases of Denmark and the United Kingdom (I2\% and I4\% respectively). 
Irrespective of significant differences among the observed EU Member States, it is evident that the revenues from excise duties on alcohol and alcoholic beverages are relatively small in size compared to total tax revenues, and total budget revenues of Member States. The average share of revenues from excise duties on alcohol and alcoholic beverages in total tax revenues (without social contributions) of EU-27 amounted to 0.9I\% in 20II, the share in total general government revenues amounted to $0.54 \%$ and in GDP of $0.24 \%$. In this context, the Croatian figures are slightly above the EU-27 average with the share of revenues from excise duties on alcohol and alcoholic beverages in total tax revenues of 1.I8\%, in total general government revenues of $0.67 \%$ and in GDP of $0.25 \%$. Figure 2 shows the structure of revenues from EU harmonized excise duties in $2 \mathrm{OII}^{6}$.

Revenues from excise duties on alcohol in the observed 27 EU Member States constitute less than IO\% of total revenues from harmonized excise duties (9.4\%), which is significantly lower than those of tobacco products (25.1\%) and energy products and electricity (65.5\%). The highest shares of revenues from excise duties on alcohol in total revenues from harmonized excise duties are recorded in Lithuania (25.4\%), Estonia (23.8\%), Finland (21.7\%) and the United Kingdom (21.3\%), and the lowest in Luxembourg (2.2\%) and Italy (2.5\%). The share of revenues from excise duties on alcohol in total revenues from harmonized excise duties in Croatia is somewhat lower than the European average and amounts to $8.1 \%$, which is also significantly lower than the share of tobacco products (33.8\%) and energy products and electricity (58.I\%).

\section{Figure 3}

Scatter plot of annual beer consumption (in litres of pure alcohol) and budget revenues from excise duties on beer (in EUR) per single adult in 2009

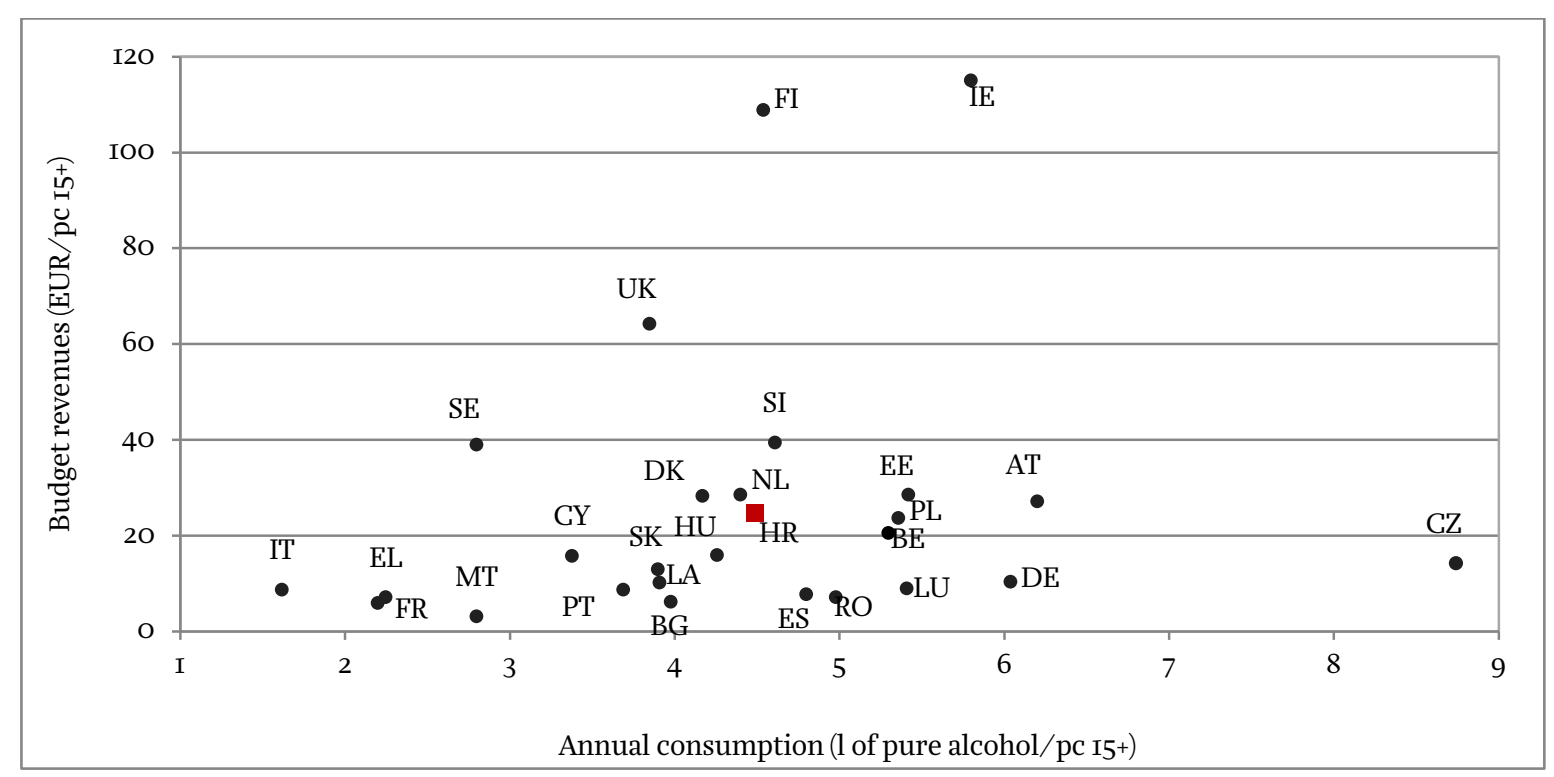

Source: Author's adjustment based on European Commission (20I2a) and Global Health Observatory, Eurostat and Ministry of Finance databases

Applied excise duty rates on beer differ significantly among countries (see Figure AI in Appendix), and certain countries apply large number of different rates, which additionally complicates the excise duty system. This primarily relates to reduced rates for small independent breweries, the differences in excise duties being defined according to their annual production. The development

\footnotetext{
${ }^{6}$ EU harmonized excise duties denote excise duties on the group of products for which the legal framework was set up on the establishment of internal market on I January 1993. These are alcohol and alcoholic beverages, tobacco products and energy products and electricity. Revenues from these excise duties represent the largest share of total excise duties receipts. According to Taxes in Europe database (European Commission), the share of unharmonized excise duties in total excise duties receipts is relatively significant only in the cases of Denmark and the United Kingdom (I2\% and I4\% respectively).
} 
and significance of the brewing industry also impacts the rates applied in a certain country, thus excise duties on beer are significantly lower in countries with larger beer production (like for instance Germany, Belgium and the Czech Republic). The four countries that apply the highest excise duties are Ireland, the United Kingdom, Sweden and Finland, and these are exactly the countries with the highest budgetary revenues from excise duties on beer. Especially interesting in Figure 3 is the Czech Republic with significantly high beer consumption of 8.7 litres of pure alcohol per single adult person, but at the same time relatively low budget revenues from excise duties on beer. This is the result of the application of a relatively low standard rate of I.28 EUR per one Plato degree contained in one hectolitre of finished product, as well as five additional reduced rates that are applied to small independent breweries.

\section{Figure 4}

Scatter plot of annual consumption of alcohol and alcoholic beverages other than beer (in litres of pure alcohol) and budget revenues from excise duties on alcohol and alcoholic beverages other than beer (in EUR) per single adult in 2009

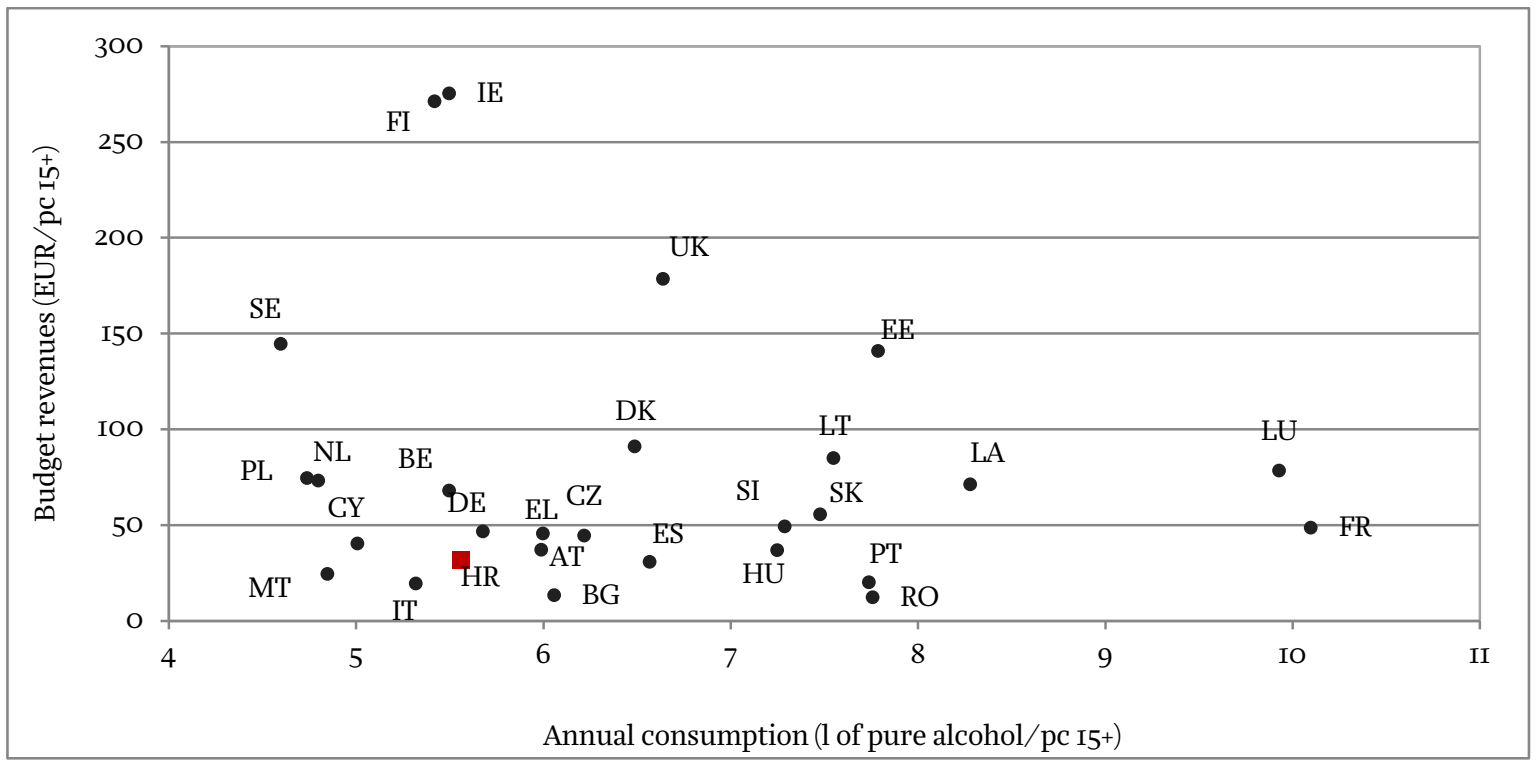

Source: Author's adjustment based on European Commission (2012a) and Global Health Observatory, Eurostat and Ministry of Finance databases

From Figures A2-A5 shown in the Appendix it can be noted that Ireland, United Kingdom, Sweden and Finland generally apply the highest standard rates of excise duty on alcohol and alcoholic beverages other than beer. Figure 4 shows that these countries also collect the highest budgetary revenues from excise duties on alcohol and alcoholic beverages other than beer. Luxembourg and France, the two European countries that are the biggest wine consumers with 7 litres of pure alcohol per single adult person, apply at the same time very low excise duties on wine which brings relatively low budget revenues from excise duties on wine compared to recorded consumption.

\section{Problems in the EU ALGOHOL TAXATION SYSTEM}

Although excise duties on alcohol and alcoholic beverages belong to EU harmonized excise duties, the legal framework for EU Member States comprises the Directive by which only minimum rates of excise duties by certain types of alcoholic beverages are set. Thus there are evident significant differences among Member States in the application of excise duty rates. These different taxation policies among Member States also lead to different levels of prices of alcohol and alcoholic beverages. Alcoholic beverages price indices by EU Member States are shown on Figure 5. 
Figure 5

Alcoholic beverages price index, year $201 \mathrm{II}(\mathrm{EU}-27=\mathrm{IOO})$

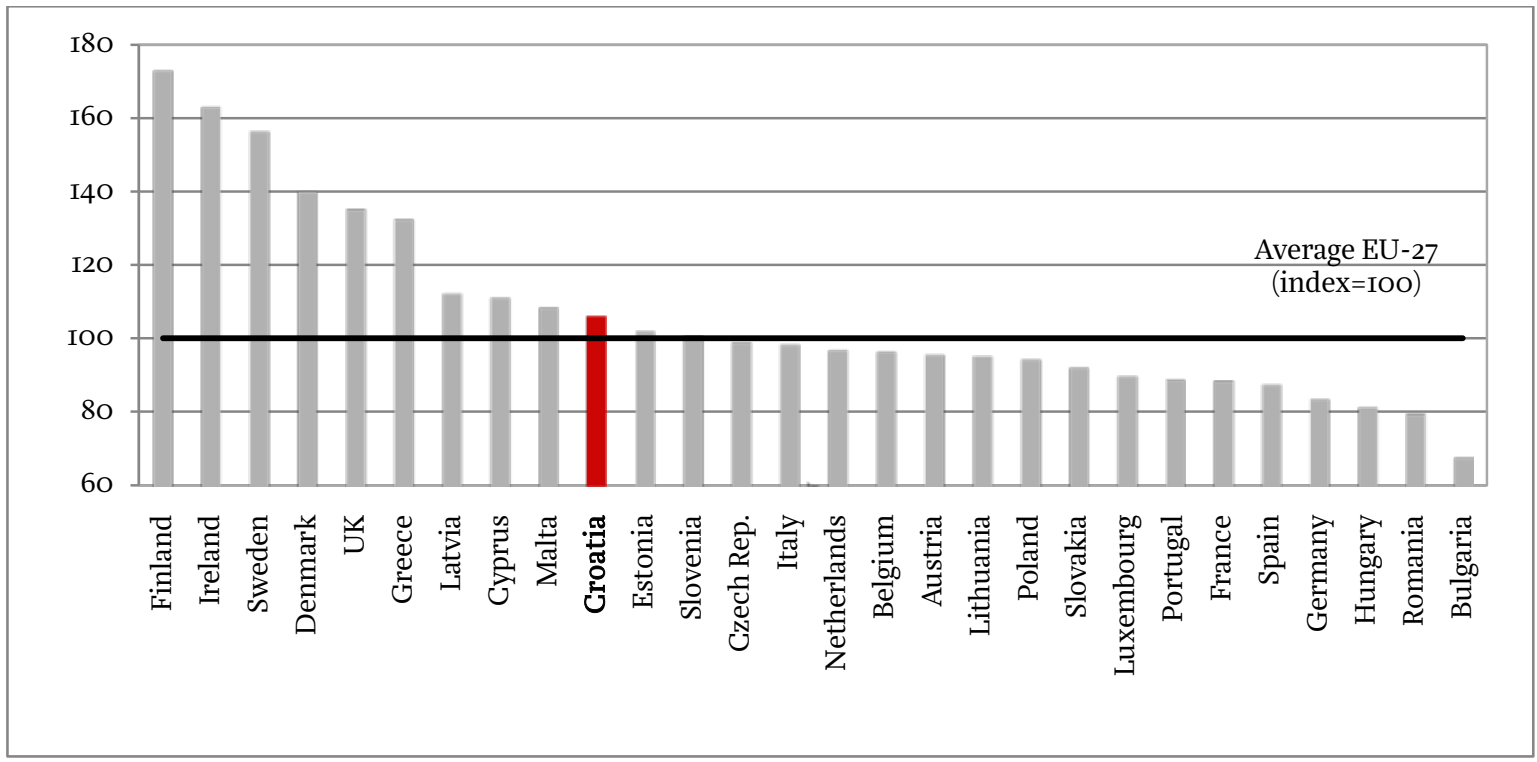

Source: Eurostat database, author's adjustment

Member States with the highest excise duty rates on alcohol and alcoholic beverages have the highest prices of these products, significantly above the EU-27 average. The alcoholic beverages price index also shows that Croatia has prices of alcoholic beverages above the EU Member State average, as well as higher than those in the neighbouring countries. However, the price differences among Member States are not necessarily caused by excise duties, since VAT, which is levied on the product retail price, may also have a significant impact on prices. On alcohol and alcoholic beverages the standard VAT rate is applied, which significantly varies in the EU from the lowest $15 \%$ in Luxembourg to the highest $27 \%$ in Hungary (European Commission, 2013b). The Croatian VAT rate of $25 \%$ is one of the highest in the EU and higher than those in the neighbouring countries (except Hungary). London Economics (2010:5I) shows that tax rate is only one aspect of the price differentials. In fact, exchange rates, affordability (which could be a result of different tastes or purchasing power of its citizens), production costs (costs of transportation or distribution of the beverages, or the competitive structure of the distribution chain if competitive forces are driving prices down in some Member States compared to others), or enforcement of the tax regime (or whether contraband alcohol is significant) are all countryspecific intrinsic factors that help explain price differences among Member States. However, Rabinovich et al. (2012:138-I39) have shown with the example of beer and spirits that the level of excise duty is positively correlated with product price, that is higher excise duties imply higher product prices.

One problem in the common taxation of alcohol and alcoholic beverages is also the real value of the minimum excise duties. Article 8 of Council Directive 92/84/EEC of 19 October 1992 on the approximation of the rates of excise duty on alcohol and alcoholic beverages envisages the examination of minimum excise duty rates every two years, taking into account the proper functioning of the internal market, competition between the different categories of alcoholic drinks, the real value of the rates of duty and the wider objectives of the Treaty. However, the minimum rates have remained unchanged since 1993 when they were formally introduced, although their revalorisation has been proposed in several occasions in line with price levels changes. The Report on the rates of excise duty applied to alcohol and alcoholic beverages (Commission of the European Communities, 2004) suggested considering a revalorisation of minimum excise duty rates of about $24 \%$ which was deemed required in order to avoid minimum 
rates becoming meaningless over time. Two years later, in 2006, Proposal for Council Directive amending Directive 92/84/EEC suggested revalorising the minimum rates on alcohol, intermediate products and beer in line with inflation from 1993 to 2005, which is in the order of 3I\%, to take effect from I January 2008. Nevertheless, neither of these changes were adopted in the end. According to Eurostat data, in the period from 1996 to 2012 alcoholic beverages prices measured by the harmonized consumer price index of EU-27 increased by $36.5 \%$, while the overall prices increase in that period amounts to $60.2 \%$. It can be definitely expected that a revalorisation of minimum excise duty rates at the EU level will be necessary in the forthcoming period.

Some other economically unfavourable phenomena arise also from (higher) levels of prices, and these are the legal cross-border trade and especially illegal activities like smuggling and other ways of evading taxation. London Economics (2010:56) shows that countries with higher price differentials are also the ones with higher recorded figures of cross-border trade of alcohol. The problem is especially pronounced in certain EU countries like Denmark, Sweden, Finland (London Economics, 20I0:56). According to the High Level Group on Fraud in the Tobacco and Alcohol Sectors (1998:20) budget revenue losses of the EU-I5 due to the illegal market were estimated to nearly I.5 billion EUR in 1996. However, Rabinovich et al (2012:I5I) state that the overall net effect of a change in the price of alcohol products is still positive, meaning that the increases in price (such as through increases in taxation) and changes in alcohol-related harm in a way bypass the issue of accounting for shifts to unrecorded consumption. The significance of smuggling, especially on the Eastern Border of the EU, has been also recognized by the European Commission which has identified a number of mainly short and medium-term actions to be carried out with the help of the Member States, as well as Russia and the Eastern Partnership countries (Armenia, Azerbaijan, Belarus, Georgia, Moldova and Ukraine). In its activity plan the European Commission stressed that Member States with high excise rates need to exercise appropriate internal control. Those bordering third countries need to increase controls both on internal consumption and on smuggling from their neighbours, contributing towards stopping outflows from their territory towards other Member States (European Commission, 20II:4). On the accession of Croatia to the EU a large part of Croatian border territory will also represent the external border of EU with third countries. Thus it is very important to implement intensified controls on Croatian state borders, which is also one of the requests for fulfilling the Schengen standards. However, the new Excise Duty Act also brings some new and more detailed provisions on the implementation of controls (more effective legal framework for suppressing, preventing and penalising illegalities and tax evasion), as well as comprehensive measures and activities preventing offences and punishing offenders (Kuliš, 2013:8).

Although classification of taxable products within the EU is conducted according to the Combined Nomenclature of goods, the definitions and equal treatment of alcohol products are still not fully resolved despite numerous efforts at harmonization. The London Economics study (2010:68-73) identified two key problems in the existing classification system. The first problem relates to the lack of certainty over the tax treatment in cases where amounts of ethyl alcohol have been added to a fermented beverage. In the other case there are questions about the tax treatment of products that have either been subject to a cleaning-up process (ultra-filtration, reverse osmosis, etc.) or produced using cleaned-up alcohol. Detailed analysis and characterization of alcohol products conducted by Segebarth et al (2008:3) showed that it is likely to be extremely difficult or even impossible to create workable general models based on analytical methods. The case-to-case approach to classification applied by Member States remains therefore the only possible approach in the context of the current legislation.

Taking into account the broader objectives of the EU Treaty, with respect to taxation of alcohol and alcoholic beverages it is necessary to have in mind also the objectives of the health and 
agricultural policies, although some Member States have not fully considered these objectives upon setting the excise duty rates. Related to agricultural policies, the taxation of wine is still an issue. Only 12 of the current 27 EU Member States apply excise duty to wine. The majority of countries that are known as famous wine producers, just like Croatia, do not apply excise duty on wine or apply very low rates (e.g. France). On the other hand, the excise duty on sparkling wine is applied in as many as I7 EU Member States, although there is also a possibility of exempting this wine from excise duty taxation. However, the question of tax treatment of still and sparkling wine is still an open issue because sparkling wines are in some countries traditionally considered luxury products (e.g. Germany and Austria), and the rate of tax levied on them is higher (Kuliš, 2005:34). Wine production is additionally supported within the EU Common Agricultural Policy. These supports are aimed at improving the competitiveness of European wine producers, ensuring EU wine production matches demand, and at the elimination of wasteful public intervention in EU wine markets. The annual amounts of these supports are not immaterial ${ }^{7}$. Hence, the economic and political importance of these subsidies makes it hard to progress from a public health perspective, i.e. encourage the decrease of consumption.

\section{CONGLUSION}

Alcohol taxation has different social, health and economic implications. However, the fiscal implications, i.e. an increase in public revenues, are almost always the main reason for the imposition of excise duties. Since the EU Directive sets only minimum rates for the taxation of alcohol and alcoholic beverages, there are numerous differences among Member States in the application of excise duties and the budgetary revenues derived from alcohol levies. The countries that apply the highest excise duties on alcoholic beverages are Ireland, United Kingdom, Sweden and Finland, and these are exactly the countries with the highest budget revenues from excise duties. Those countries with powerful alcohol industries, like France with wine and the Czech Republic with beer, are susceptible to lobbying from interest groups, so they generally have lower excise duty rates. This is manifested in lower budget revenues from excise duties on alcoholic products.

Aside from the differences among excise duty rates applied, another problem in the common taxation of alcohol and alcoholic beverages is the real value of minimum excise duties, since the minimum rates have remained unchanged since 1993. Alcoholic beverages prices measured by harmonized consumer price index of EU-27 increased by 36.5\% from I996 to 20I2, while the overall prices increase in that period amounts to $60.2 \%$. For the purpose of establishing economic balances in the internal EU market, as well as to attain the healthcare, social and fiscal objectives of the common alcohol taxation, a minimum excise duty rate revalorisation at the EU level and continuous harmonization to account for at least the annual inflation rate are necessary.

A big problem in the EU alcohol taxation system is represented by excise duty revenue losses due to legal cross-border trade, but even more so due to illegal activities like smuggling and other forms of tax evasion. Therefore all Member States, and especially those with high excise duty rates, have to put additional efforts into exercising the appropriate internal controls. Member States bordering on third countries need to increase controls both on internal consumption and on smuggling from their neighbours, contributing towards stopping outflows from their territory.

Open issues related to the lack of certainty over the tax treatment in cases where some amounts of ethyl alcohol have been added to a fermented beverage, as well as the tax treatment of products that have been subject to a cleaning-up process or are produced using cleaned-up alcohol should

\footnotetext{
${ }^{7}$ Anderson and Baumberg (2006:343) state that the annual amount of EU support for wine production amounts to around EUR I.5 billion.
} 
definitely be resolved in the forthcoming period. Furthermore, it is necessary to have in mind also the objectives of the health and social policies, and harmonize these objectives with the objectives of agricultural policies, especially in the context of wine production support. Both these issues require additional analyses since they may (and probably do) lead to certain economic imbalances.

Croatian excise duties on alcohol and alcoholic beverages are already fully harmonized with minimum requirements and rates set by the EU. In Croatian legislation, the reduced rates for small independent beer producers applied by almost all EU Member States are not envisaged. Upon the accession of Croatia to the EU, provisions of the new Excise Duty Act (NN 22/13) related to alcohol and alcohol beverages taxation will enter into force, although no changes in the amounts of excise duties on alcohol and alcoholic beverages will ensue.

\section{LITERATURE}

Anderson, P. i Baumberg, B., 2006. Alcohol in Europe - A public health perspective. London: Institute of Alcohol Studies.

Cnossen, S., 2006. Alcohol Taxation and Regulation in the European Union. CESifo Working Paper, No. I82I.

Commission of the European Communities, 2004. Report from the Commission to the Council, the European Parliament and the European Economic and Social Committee on the rates of excise duty applied on alcohol and alcoholic beverages. Bruxelles: Commission of the European Communities.

Commission Regulation (EC) No 3199/93 of 22 November 1993 on the mutual recognition of procedures for the complete denaturing of alcohol for the purposes of exemption from excise duty. Bruxelles: European Commission.

Council Directive 92/83/EEC of I9 October 1992 on the harmonization of the structures of excise duties on alcohol and alcoholic beverages. Bruxelles: European Commission.

Council Directive 92/84/EEC of 19 October 1992 on the approximation of the rates of excise duty on alcohol and alcoholic beverages. Bruxelles: European Commission.

European Commission, 20II. Commission Anti-fraud Strategy - Action plan to fight against smuggling of cigarettes and alcohol along the EU Eastern border. Bruxelles: European Commission.

European Commission, 20I2a. Excise duty tables - Tax Receipts Alcoholic Beverages - July 2012. Bruxelles: European Commission.

European Commission, 20I2b. Excise duty tables - Tax Receipts Manufactured Tobacco - July 2012. Bruxelles: European Commission.

European Commission, 2012c. Excise duty tables - Tax Receipts Energy products and Electricity July 20I2. Bruxelles: European Commission..

European Commission, 2013a. Excise duty tables - Part I Alcoholic Beverages - Situation at Ist January 2013. Bruxelles: European Commission.

European Commission, 2013b. VAT Rates Applied in the Member States of the European Union Situation at I4th January 2013. Bruxelles: European Commission.

European Commission: Taxation and Customs Union. Taxes in Europe database. Bruxelles: European Commission.

Eurostat database. Available at: http://epp.eurostat.ec.europa.eu/portal/page/portal/statistics /search_database].

Global Health Observatory database. Global Information System on Alcohol and Health - Levels of Consumption. Available at: [http://apps.who.int/gho/data/]. 
High Level Group on Fraud in the Tobacco and Alcohol Sectors, 1998. Report to Directors General for Customs and Indirect Taxation.

Kuliš, D., 2005. Trošarine na alkohol i alkoholna pića in: D. Kuliš. Plaćamo li Europske trošarine? Zagreb: Institute of Public Finnce/Friedrich Ebert Stiftung, 3I-4I.

Kuliš, D., 2013. Excise duties system in Croatia closer to the European system. Newsletter, No. 75. Zagreb: Institute of Public Finance.

London Economics, 20IO. Study analysing possible changes in the minimum rates and structures of excise duties on alcoholic beverages. Final Report to EC DG Taxation and Customs Union.

Ministry of Finance of Republic of Croatia. Time Series Data. Zagreb: Ministry of Finance.

Proposal for Council Directive amending Directive 92/84/EEC on the approximation of the rates of excise duty on alcohol and alcoholic beverages.

Rabinovich, L. [et al.], 20I2. Further study on the affordability of alcoholic beverages in the EU. Bruxelles: European Commission.

Segebarth, N. [et al.], 2008. Analysis and Characterisation of Alcoholic Products (ACAP). FISCALIS Project Group - Final Report. Luxembourg: Office for Official Publications of the European Communities.

Smith, S., 2005. Economic Issues in Alcohol taxation in: S. Cnossen, ed. Theory and Practice of Excise Taxation, 56-83. New York: Oxford University Press Inc.

The Brewers of Europe, 20I2. Excise Duty Rates for Beer in Europe - Rates as at: I October 2012.

WHO, 2012. Alcohol in the European Union - Consumption, harm and policy approaches. Copenhagen: WHO Regional Office for Europe.

Zakon o trošarinama, NN 83/o9, I/IO, III/I2 i 22/I3. Zagreb: Narodne novine. 


\section{APPENDIX - COMPARISON OF STANDARD EXGISE DUTY RATES BY COUNTRIES ${ }^{8}$}

\section{Figure AI}

Excise duty rates in force and standard-adjusted excise duty rates on beer, in EUR per hectolitre of finished product, situation at Ist January $2013^{9}$

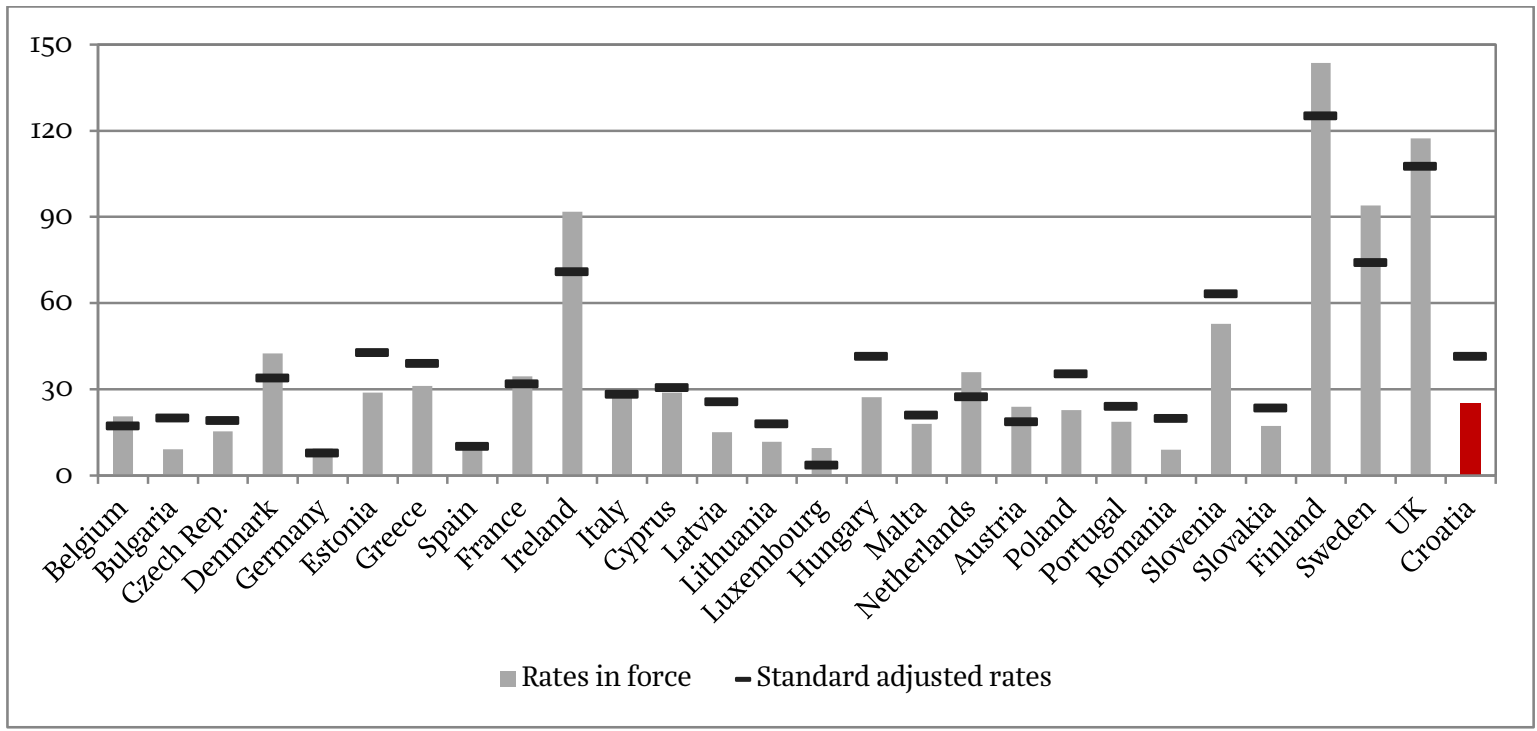

Source: European Commission (2013a); author's calculation

\section{Figure A2}

Excise duty rates in force and standard-adjusted excise duty rates on still wine, EUR per hectolitre of product, situation at Ist January 2013

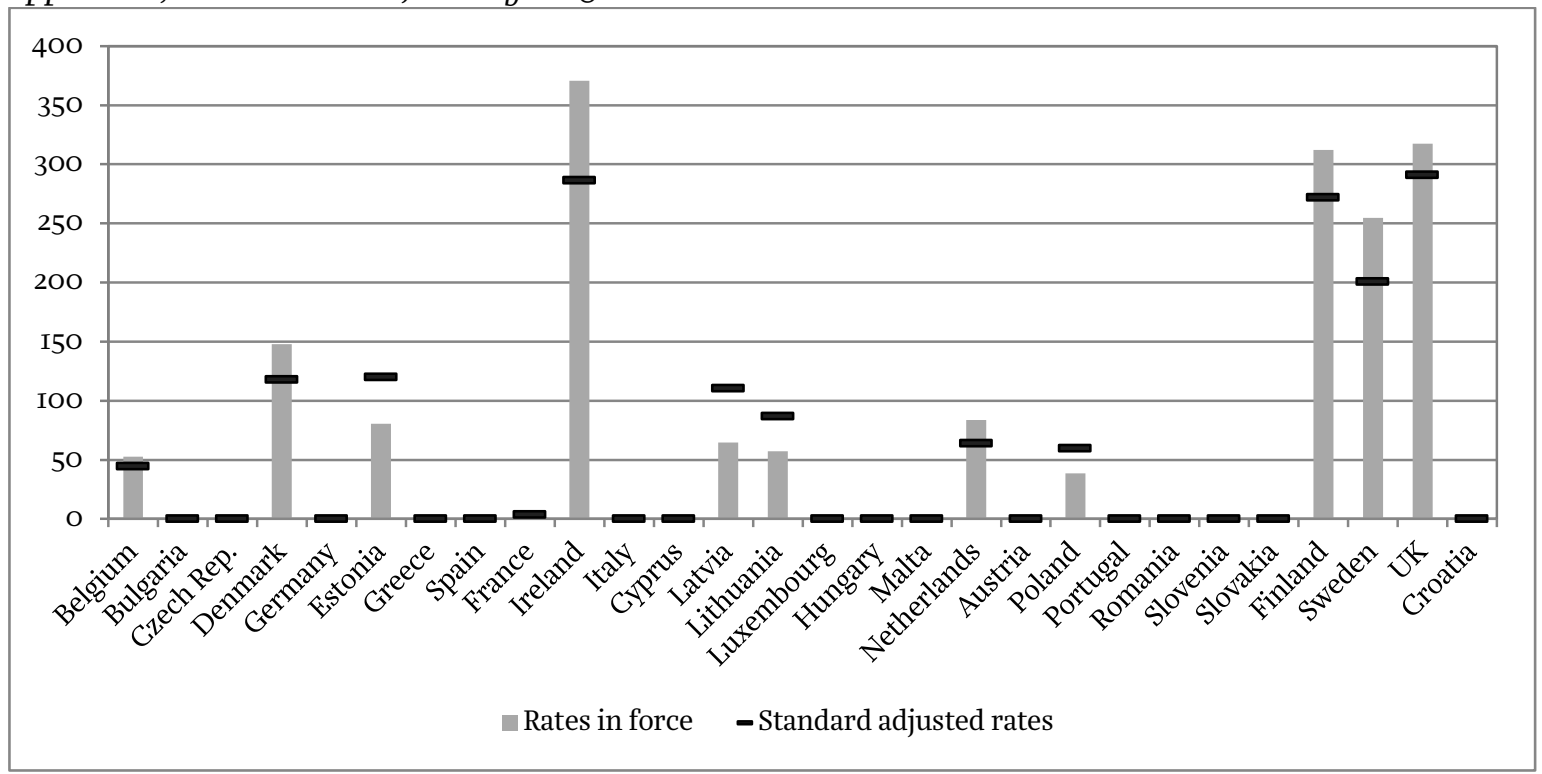

Source: European Commission (2013a); author's calculation

\footnotetext{
${ }^{8}$ Standard-adjusted rates are calculated as excise duty rates in force divided by GDP per capita measured by purchasing power standard $(\mathrm{EU}-27=\mathrm{I})$. In that way expressed are comparable excise duty amounts by countries which take into account differences in living standard among the observed countries.

${ }^{9}$ For comparison purpose of excise duty rates in force by countries rates per hectolitre for average beer strength were taken, with $12^{\circ}$ Plato or $4.8 \%$ alcohol by volume (for more details see The Brewers of Europe, 20I2).
} 
Figure A3

Excise duty rates in force and standard-adjusted excise duty rates on sparkling wine, EUR per hectolitre of product, situation at Ist January 2013

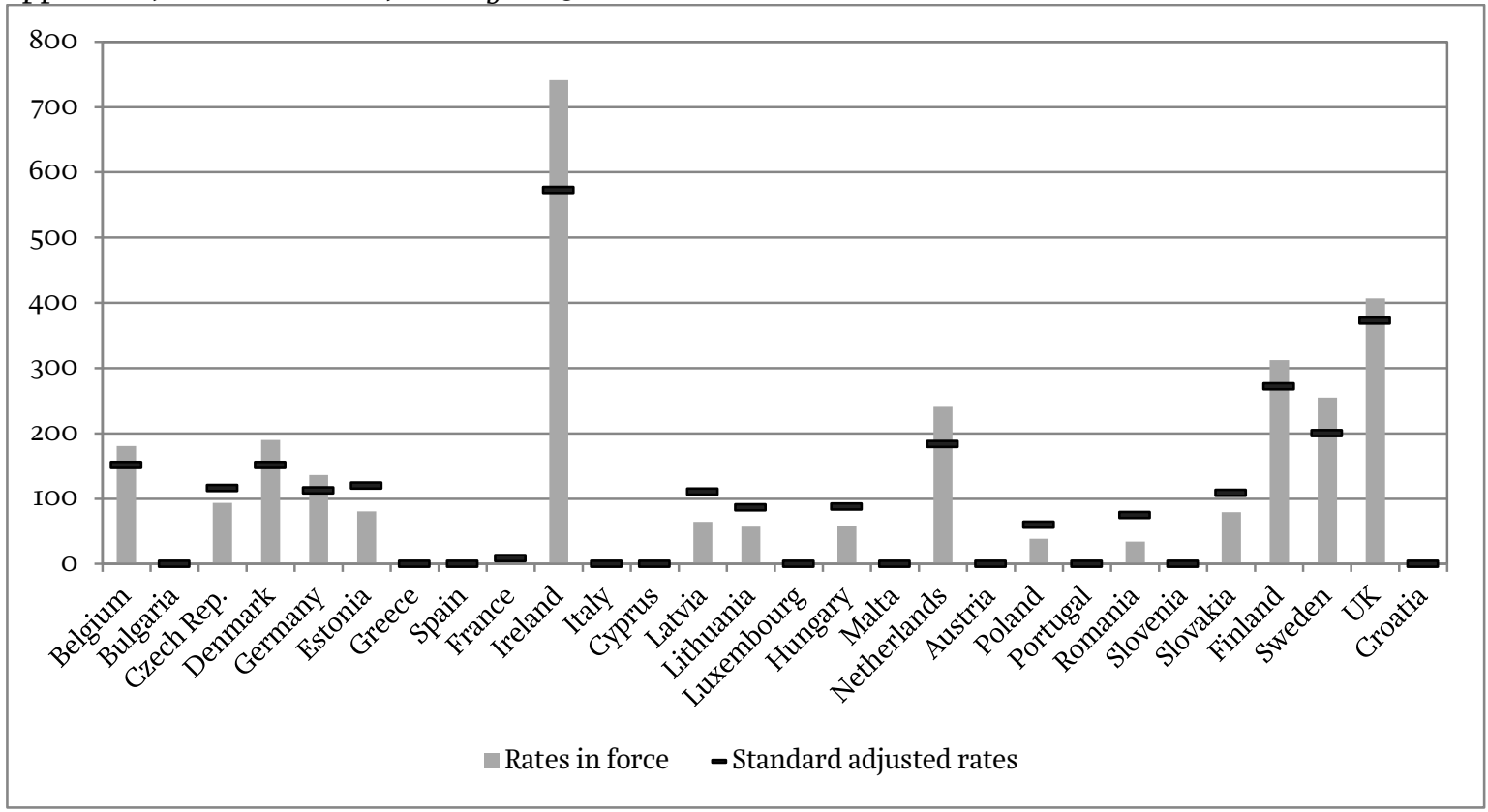

Source: European Commission (2013a); author's calculation

\section{Figure A4}

Excise duty rates in force and standard-adjusted excise duty rates on intermediate products, EUR per hectolitre of product, situation at Ist January 2013

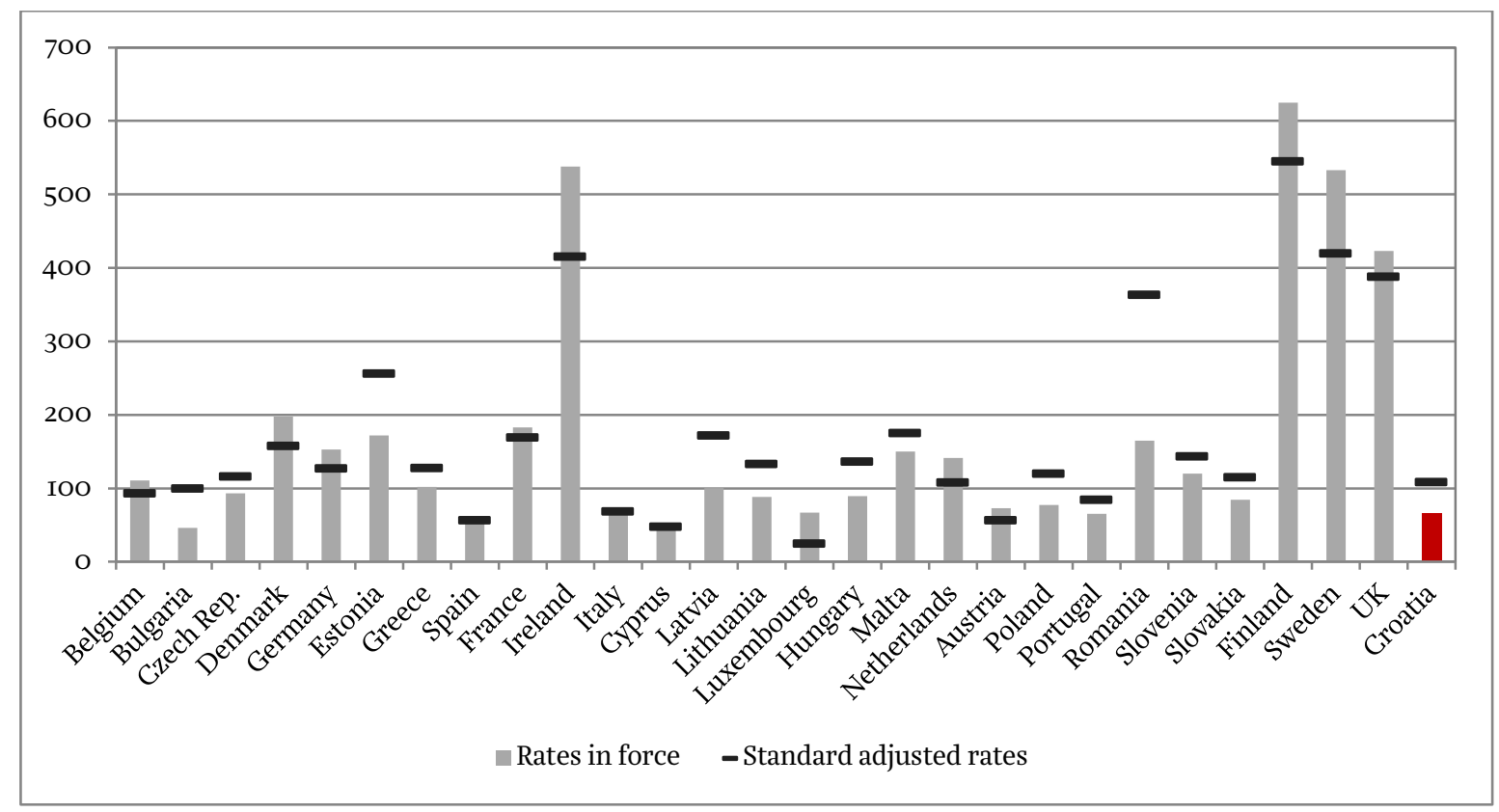

Source: European Commission (2013a); author's calculation

I4 NEWSLETTER 76 | PETAR SOPEK | The alcohol taxation system in EU and Croatia | Institute of Public Finance 
Figure A5

Excise duty rates in force and standard-adjusted excise duty rates on ethyl alcohol, EUR per hectolitre of pure alcohol, situation at Ist January 2013

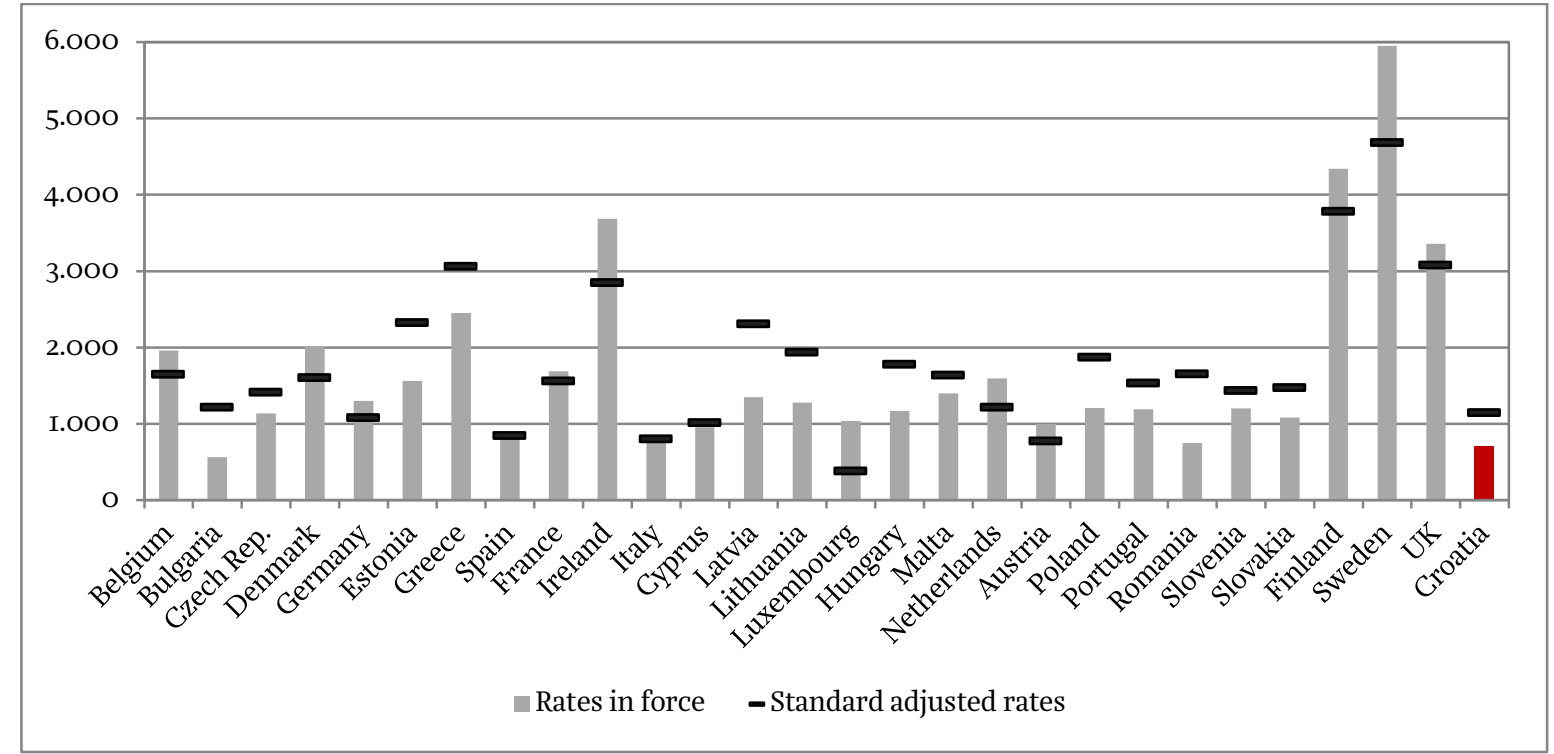

Source: European Commission (2013a); author's calculation 